\title{
Retrofitting of Infilled Frame in Reinforced Concrete Structure
}

\author{
Wajid Ali ${ }^{1}$, Syed Azmat Ali Shah², Khan Shahzada ${ }^{1 b}$, Syed Mohammad Ali' ${ }^{1 \mathrm{c}}$, \\ Sajjad Wali Khan ${ }^{1 \mathrm{~d}}$
}

RECEIVED ON 22.01.2019, ACCEPTED ON 26.07.2019

\begin{abstract}
This research work aims to compare the seismic performance (in terms of lateral load strength, stiffness, ductility, response modification factor and performance levels) of full scale infilled frames before and after retrofitting. To evaluate the seismic performance, two infilled frames with door opening at different locations were constructed in the laboratory based on the current construction practices in Pakistan. In one infilled frame, door opening was at the center (Frame-1) while in other, door opening was at a side (Frame-2). After construction, both the specimens were tested with quasi-static test. The damaged parent specimens were then retrofitted with Ferrocement overlay and cracks in the infill wall were repaired with grout injection. Steel door frames of gauge 18 were installed at the door opening to make the model more realistic. Results obtained after performing quasi static test on the retrofitted specimen have showed that the specimens not only gained the original strength, but the seismic parameters of the infilled frames were observed to have also improved.
\end{abstract}

KEYWORDS: Ferrocement Overlay, Infilled RC Frame, Performance Levels, Quasi Static Test, Response Modification Factor, Retrofitting, Seismic Performance.

\section{INTRODUCTION}

$\mathrm{T}$ The Building Code of Pakistan Seismic Provision (BCP SP) was developed in 2007, after the unusual and unprecedented Kashmir earthquake of 2005 [1]. Buildings in the areas affected by the said earthquake, suffered minor to major damage, and in some cases complete collapse. The main reasons behind the huge damage of buildings were low awareness about the earthquake, lack of seismic design codes and due to the major issues regarding construction practices i.e. poor quality of concrete, poor quality of mortar used in construction of walls and weak connections at the corners [2]. The infill walls and beam column joints in RC Reinforced Concrete (RC) frames may experience damages during an earthquake due to the design errors, poor detailing, and poor construction practices. The presence of cracks in the infill wall and development of plastic hinges leads to the inadequate lateral strength and stiffness of the infilled frame [3]. Existing non-engineered RC buildings which were not designed and constructed according to the BCP-2007 are vulnerable to earthquakes To survive the future earthquakes, the existing RC buildings can be upgraded to a desired level of performance against the

${ }^{1}$ Department of Civil Engineering, University of Engineering and Technology Peshawar, Khyber Pakhtoonkhwa, Pakistan.

Email: aengrwajidali@uetpeshawar.edu.pk (Corresponding Author), bkhanshahzada@uetpeshawar.edu.pk,

cbridge_doctor@yahoo.com, didrajjadwalikhan@uetpeshawar.edu.pk

${ }^{2}$ Centre for Disaster Preparedness and Management, University of Peshawar, Khyber Pakhtoonkhwa, Pakistan.

Email: engrazmatalishah@uop.edu.pk.

This is an open access article published by Mehran University of Engineering and Technology, Jamshoro under CC BY 4.0 International License. 
seismic loads with minimal discomfort to the occupants and with the most cost effective retrofitting procedures. To restore the pre-earthquake state of a building i-e to restore the lateral strength and stiffness of infilled RC frames and to reduce the lateral drift at the peak loads different retrofitting techniques have been recommended by researchers [4].

Most available seismic retrofitting techniques have certain degree of difficulty to be implemented on site and are thus more expensive [5]. To obtain high quality work more efficient and skilled staff are required for a given retrofitting technique [6]. Among the available retrofitting techniques (i.e. Ferrocement Overlay, Grout Injection, Shotcrete Overlay, Repointing, Stitching of Cracks, Surface Coating, FRP Fiber Reinforced Polymers (FRP), External Reinforcement, Post Tensioning and Core Cutting Technique etc.); implementation of Ferrocement overlay is very simple, easy and cost effective for enhancing the strength and stiffness of a structure [7]. This technique does not require any skilled labor and causes least disturbance to the occupants. In Ferrocement overlay a welded steel wire mesh (capable of resisting corrosion) having certain gauge (diameter) and spacing (length between two adjacent wires) is attached to the surface under consideration. Wire mesh is attached to the affected area with the help of screws and steel washers followed by plaster coating [8].

The suitability of Ferrocement Overlay as a seismic retrofit material for the first time was experimentally investigated by Reinhorn et. al. [9] testing brick masonry prisms i-e uncoated (bare brick masonry prisms) and coated (specimens coated with ferrocement overlay). The experimental results have revealed that the stiffness, strength and ductility of the coated brick masonry prisms have values nearly doubled as compared to the uncoated specimens. Ferrocement overlay can also increase the lateral strength and stiffness of the infilled frames [10], unreinforced brick masonry structures [8], unreinforced concrete block masonry buildings [11], confined masonry building [12]. Ferrocement overlay also improve the in-plane strength of masonry infilled reinforced concrete portal frame [13].
Strengthening of structural members such as beams and columns can be increased with ferrocement overlay. Results of experiment performed by researchers [14-15] have shown that flexural strength, ductility and peak failure load of columns can be increased with ferrocement overlay.

Grout injection is a famous technique which is widely used throughout the world for restoring the original strength of antique structures without changing the aesthetic and architectural appearance of the structure. The technique can be used to strengthen brick or stone masonry by injecting grout into voids or cracks to restore the pre-earthquake state of old buildings [16].

Schuller et. al. [17] investigated eight masonry piers to study the behavior of constructed specimens after grout injection. Each masonry units used in the construction of pier were reclaimed from an old building constructed back in 1915. Mortar with proportions of cement: lime: sand of 1:2:9 (by volume) was used to simulate old, deteriorated mortar. After construction each masonry piers were loaded to failure in compression to determine the compressive characteristics of old unreinforced masonry. Immediately following load removal, the piers were re-Loaded to determine the compressive behavior in the damaged state. Any severely crushed units were replaced after the removal of piers from the test apparatus. Grout (consisted of Portland cement 90\%, micro silica $10 \%$ and super plasticizer of $2 \%$ by weight) was injected into the cracks caused during the initial loading. Following a 28-day (minimum) curing period the piers were again loaded in compression to failure. Comparison of the behavior of repaired pier with that of the as-built and damaged behaviors provide an indication that grout injection up to $80 \%$ of the original masonry strength, can restore compressive behavior.

Manzouri et. al. [18] investigate the compressive behavior of eight masonry piers by grout injection. The piers were loaded to failure under compression loads. They were then unloaded and immediately loaded again to study the behavior of damaged pier. The specimens were repaired by replacing the severely crushed units and mortars. Coarse grout was injected into the collar joints and large voids while fine grout 
was injected into the finer cracks. The coarse grout was consisted of Portland cement 100 and $2 \%$ of super plasticizer by weight with a water to cement ratio of 0.50 fine grout was consisted of type I/II Cement of $32.1 \%$, Lime of $4.8 \%$, Flysh $7.9 \%$, Sand-70 55.2 and $2 \%$ of super plasticizer by weight with a water to cement ration of 1.0. The piers were tested again in compression at a minimum of 28 days after the repair. The major findings from this study [18] were that; the strength and stiffness of damaged masonry piers were fully restored with grout injection.

From the literature study, it was concluded that research on retrofitting of full scaled RC frames with infill walls having door at different locations was scant; so as a motivation an experimental program was proposed to find the seismic performance of full scaled infilled frames with different door locations and to compare the seismic performance (in terms of lateral load strength, stiffness, ductility, response modification factor and performance levels) before and after retrofitting with ferrocement overlay, cement based grout injection and installation of steel door frames.

\section{EXPERIMENTAL PROGRAMS}

In this research work; two infilled frames of single bay, single story, full scaled, having doors at different locations were constructed in the laboratory. The infilled frames simulate an internal frame within RC building and were designed according to the commonly observed RC buildings in the northern areas of Pakistan. Infilled frame having door at center was referred as Frame-1 while infilled frame having door at a side was referred as Frame-2. Each infilled frame was constructed over a reinforced concrete pad of dimensions $3657.6 \times 609.6 \times 304.8 \mathrm{~mm}$. The size of columns was $304.8 \times 304.8 \mathrm{~mm}$, whereas the width and depth of beam was $304.8 \times 304.8 \mathrm{~mm}$ respectively. Thickness of the infill wall was $228.6 \mathrm{~mm}$ and was constructed in English bond pattern in a cement-sand mortar of 1:4. Shah [19] performed quasi static test on the infilled frames under cyclic loading. Constructed Frame-1 and Frame-2 and their dimensions are shown in Figs. 1(a-b)-2(a-b).

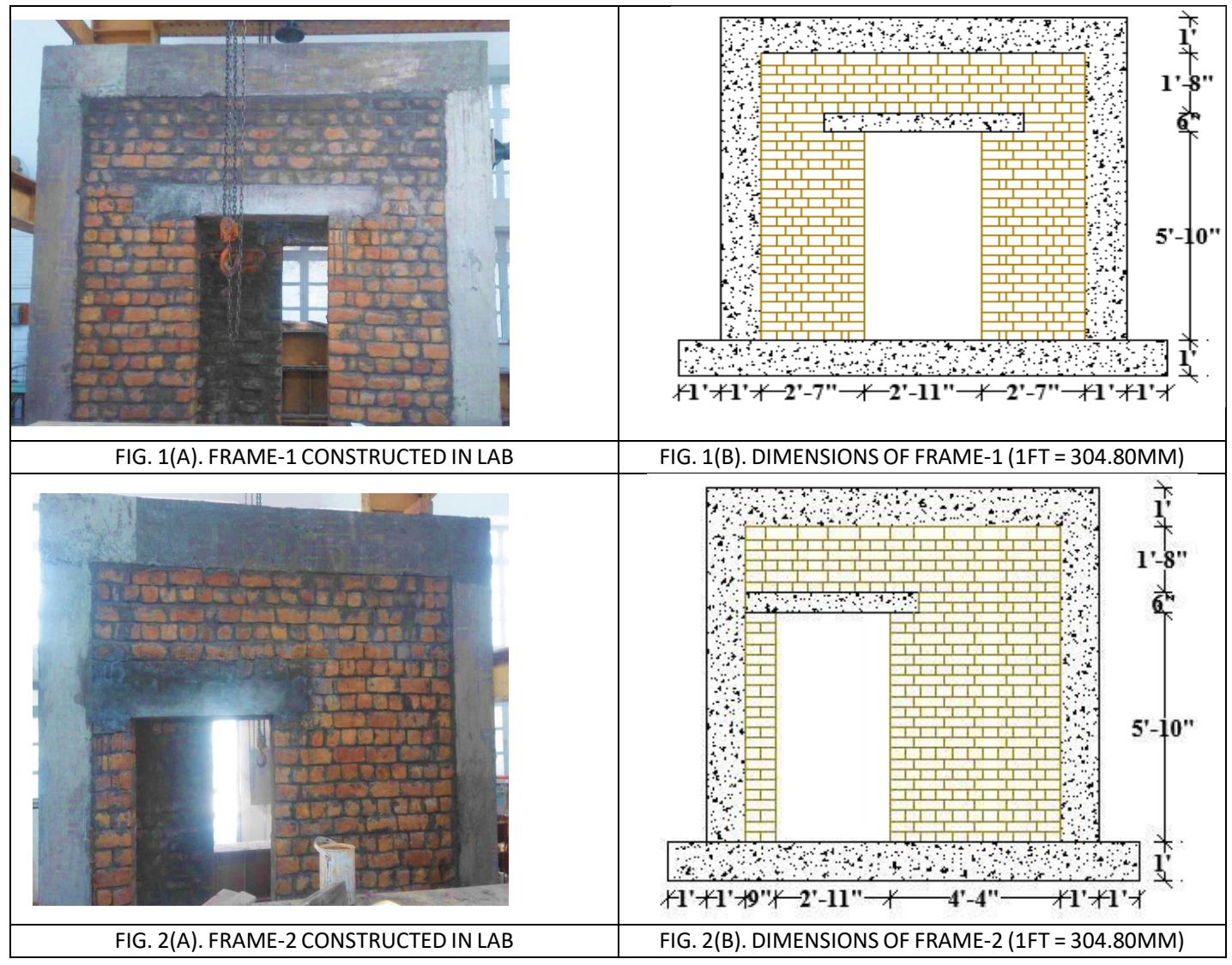

Mehran University Research Journal of Engineering and Technology, Vol. 39, No. 3, July 2020 [p-1SSN: 0254-7821, e-1SSN: 2413-7219] 


\subsection{Installation of Steel Door Frames and Repairing Damaged Areas in the Infill Wall}

Manzouri et. al. [18] endorsed that cracks having thickness greater than $19 \mathrm{~mm}$; the damaged areas can be reconstructed. On the recommendation of above researcher, those areas of the infill wall which were damaged during testing before retrofitting and were having cracks greater than $19 \mathrm{~mm}$ were dismantled. After dismantling, to make the model more realistic, steel door frames of gauge 18 were installed at the door openings which were not present in original models. Removed part of the infill was reconstructed with new masonry unit (bricks) using mortar of 1:4. The ratio of mortar used was same as that of original specimens before retrofitting. Installation of steel door frames and reconstructed portions of the infill walls are shown in Fig.3(a-b).

\subsection{Retrofitting Using Ferro-Cement Overlay}

Ferrocement overlay was used for the retrofitting of the damaged frames. According to the guidelines for application of reinforced plaster [14] the gauge and spacing of wires in a mesh should be such that to provide a minimum reinforcement ratio of $0.05 \%$ of the gross area of masonry. A corrosion resistant welded steel wire mesh of gauge 18 (diameter = $1.18 \mathrm{~mm}$ ) with a spacing between two alternative wires of $19.05 \mathrm{~mm}$ having reinforcement ratio of $0.05 \%$ was used which was compliance with the guidelines for application of reinforced plaster. Steel wire mesh was connected to the whole infilled frame including beam, columns and both sides of the infill wall, utilizing screw No.10 and steel washers of external diameter $25.4 \mathrm{~mm}$. Length of the screws used was $38.1 \mathrm{~mm}$. Steel wire mesh was overlapped through a length of $152.4 \mathrm{~mm}$. Steel wire mesh connected to the infill wall and columns is shown in Fig. 4(a-c).
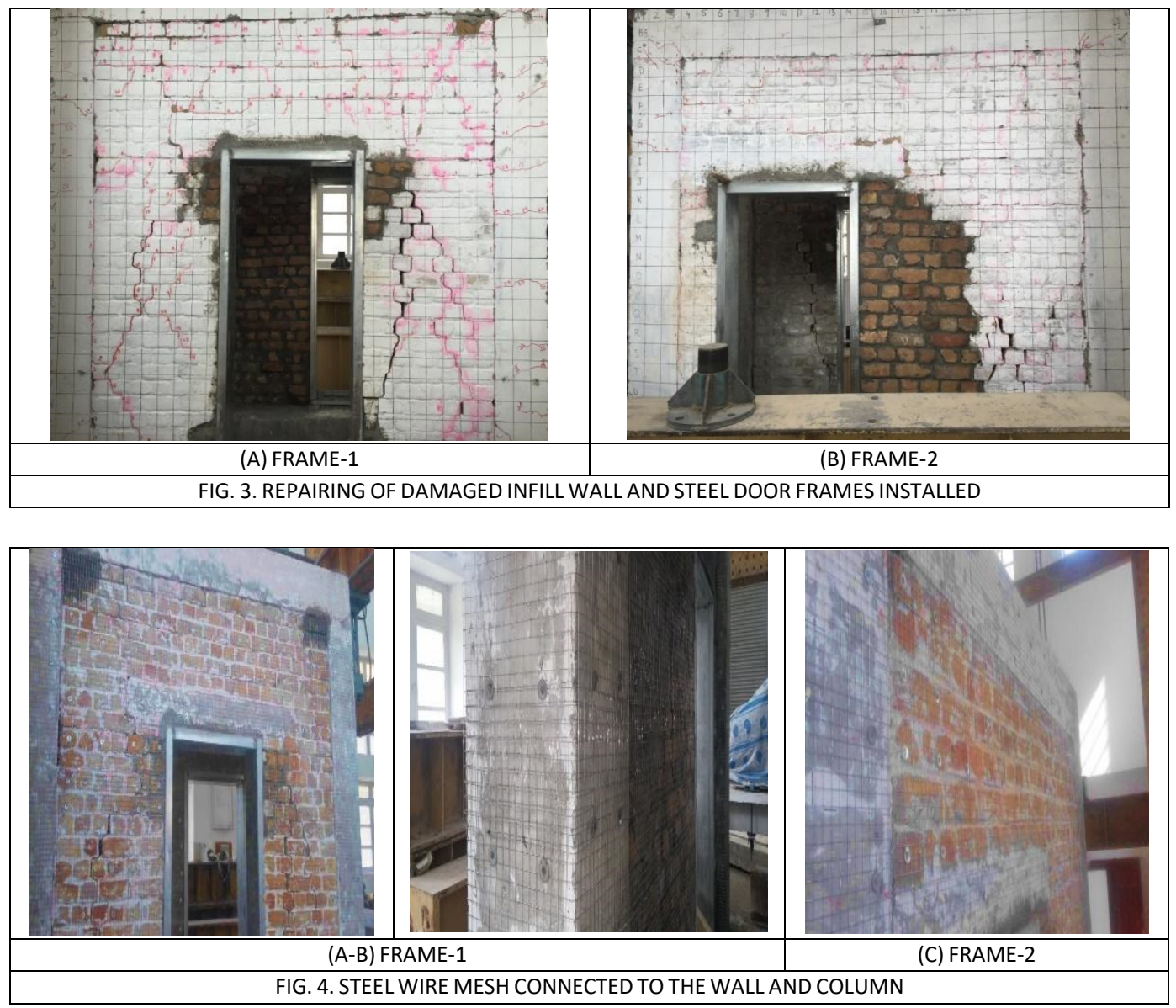

Mehran University Research Journal of Engineering and Technology, Vol. 39, No. 3, July 2020 [p-ISSN: 0254-7821, e-ISSN: 2413-7219] 


\subsubsection{Grout Injection}

Miha [16] suggested that grout injection can only be used for cracks having a width ranging from $2-10 \mathrm{~mm}$ while Schuller et. al. [17] recommended that grout injection is effective for cracks having a thickness ranging from $0.08-12 \mathrm{~mm}$. As recommended by [6 -7] cracks with width less than 10 to $12 \mathrm{~mm}$ were repaired according to the guidelines for application of grout injection [14]. Holes were drilled in mortar joints along the crack length and injection nozzles of length $101.6 \mathrm{~mm}$ and diameter of $9.525 \mathrm{~mm}$ were fixed at the drilled holes using fast binding cement paste (1:2). The distance between injection nozzles was 304.8mm. Injection ports were fixed after connecting wire mesh to the wall surface. Injection nozzles installed along the crack length in the infill wall are shown in Fig. 5(ac).

\subsubsection{Plastering}

Installation of injection ports was followed by sealing of wall surface with plaster mortar of 1:3. The prepared mortar was applied on structural members (columns and beams) and non-structural component i.e. infill wall. Plaster on wall before grouting is very effective because for grout injection sealing only cracks is not enough as the grout may come out of the surrounding areas due to high pressure, therefore the best option is to inject grout after plastering the whole surface area. Plastered Infilled Frame-1 and Frame-2 are shown in Fig. 6(a-b).

\subsubsection{Preparation and Injection of Grout into the Cracks}

With a minimum of 14 days plaster curing, grout comprised of ten parts of ordinary Portland cement, one part of slacked lime and an ultra-expansion agent at the rate of $0.005 \%$ of Portland cement was prepared based on penetrability, stability and affectivity [14]. The water to cement ratio used in grout was 0.9. Before grout injection; surface was watered to make sure that the masonry is saturated. After 24 hours of watering the surface; grout was injected from the bottom most injection nozzle and continues to flow in the upward direction. Grout coming out from each injection port was stopped by stoppers. The pressure of injection was kept between 2-4 bars so that the grout may reach to each part of the crack. When grout gained 28 days strength, the retrofitted infilled frames were tested under the same conditions (Load and boundary conditions) as they were tested before retrofitting. Grout injection machine and grout injection process is shown in Fig. 7(a-b). Mechanical properties of the materials found after performing various tests are given in Table 1.
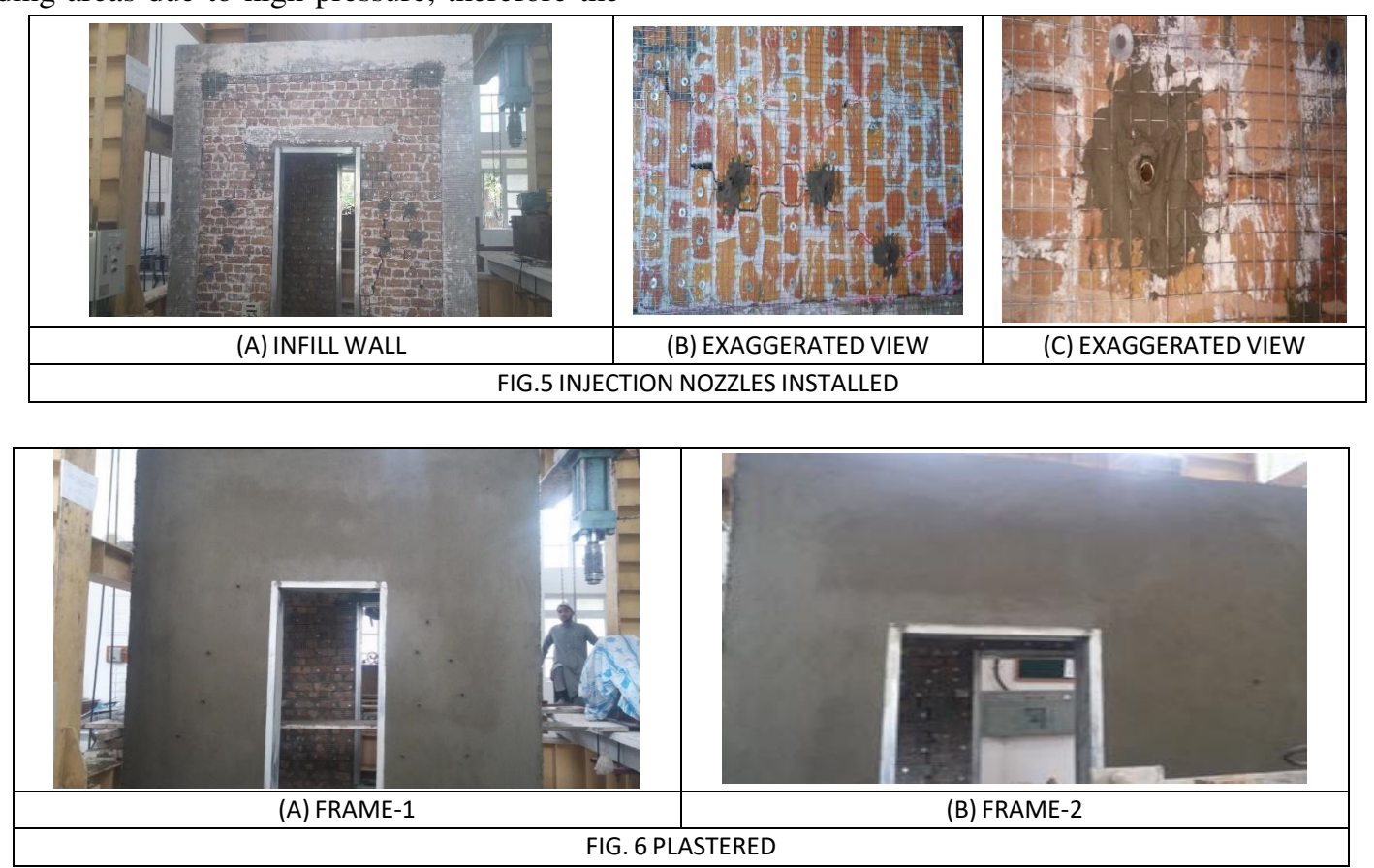

Mehran University Research Journal of Engineering and Technology, Vol. 39, No. 3, July 2020 [p-ISSN: 0254-7821, e-ISSN: 2413-7219] 


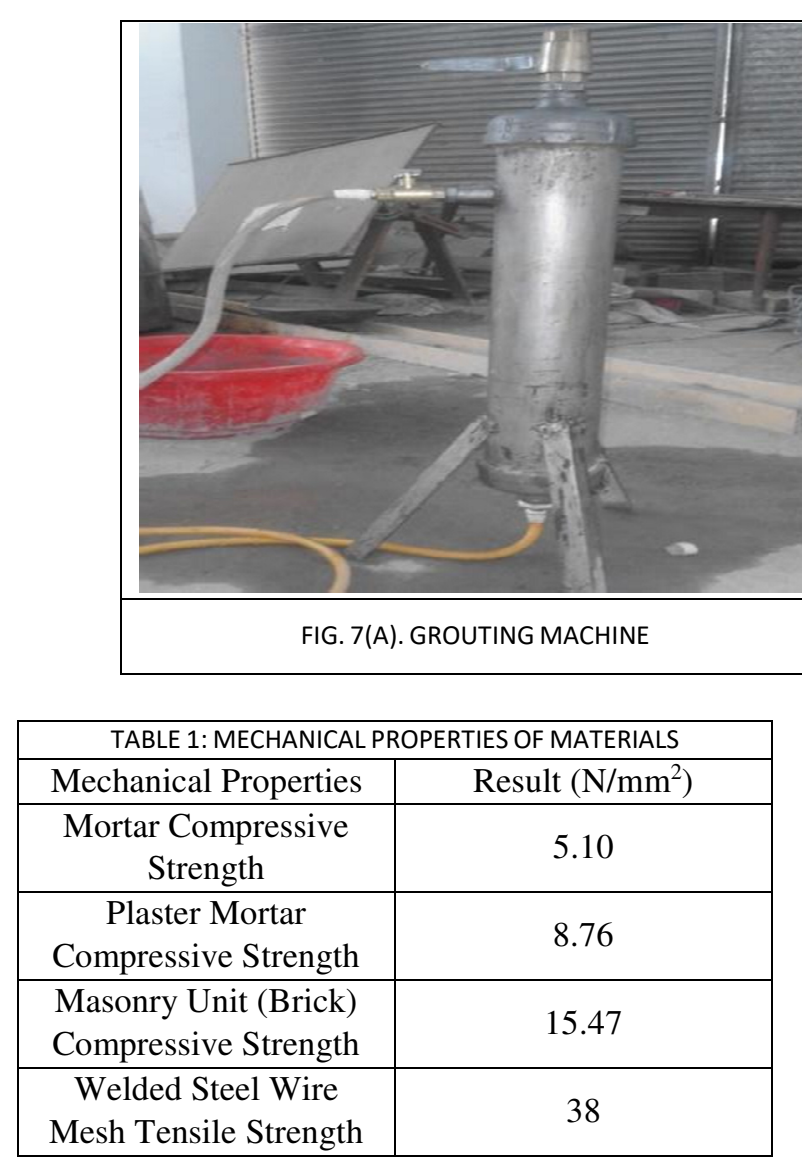

\section{INSTRUMENTAL SETUP}

In this research; displacement control test was performed in which each displacement cycle was repeated thrice as shown in Fig. 8. A horizontal hydraulic jack was applied at the end of beam to apply lateral load and vertical hydraulic jack was applied at the top mid span of beam for vertical loading. Loads and displacements were measured through a calibrated load cells, LVDT (Linear Variable Displacement Transducers) and string pot respectively that were connected to LabVIEW (data acquisition system). For recording the in-plane displacements in loading direction string pot (1) was mounted at the mid span of beam having displacement measuring capacity of $500 \mathrm{~mm}$. Five LVDT having capacity of $50 \mathrm{~mm}$ were used at different locations to record the displacements. LVDT 2 and 3 were used to record the displacements in the infill wall. For vertical displacement at the columns base, LVDT 4 and LVDT 5 were used. Out of plane displacements were recorded by LVDT 6 .

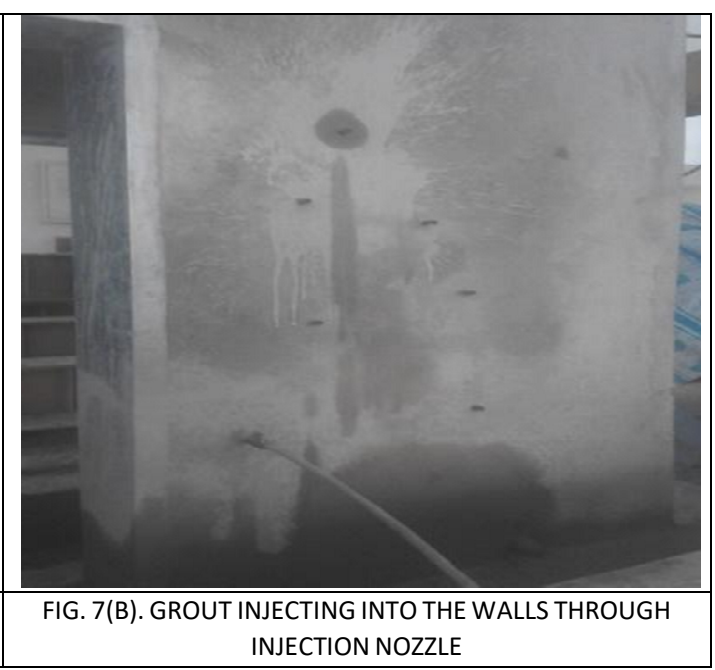

Instrumentation setup for Frame-1 and Frame-2 are shown in Figs. 9-10.

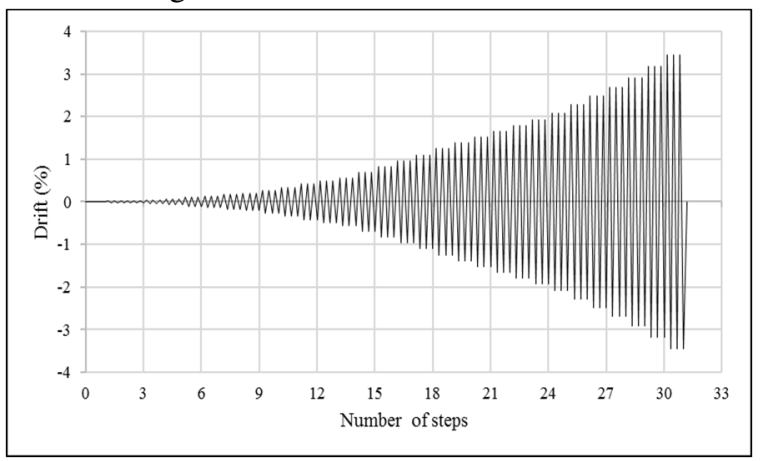

FIG. 8. DISPLACEMENT CYCLES

\section{EXPERIMENTAL RESULTS AND DISCUSSIONS}

The Frames results are discussed in terms of Damage mechanism, Hysteresis loops, Capacity curves, Bilinear idealization of capacity curves, Stiffness degradation and Performance levels.

\subsection{Damage Mechanism}

For tracing the location of cracks on the specimen, grids of $100 \times 100 \mathrm{~mm}$ were drawn on each frame after the white wash.

\subsubsection{Damage Mechanism of Frame-1}

The final crack pattern of the Frame- 1 before and after retrofitting is shown in Fig. 11. Before retrofitting; in each masonry piers diagonal cracks were originated Mehran University Research Journal of Engineering and Technology, Vol. 39, No. 3, July 2020 [p-ISSN: 0254-7821, e-ISSN: 2413-7219] 
from the corners of door opening and moved diagonally towards the end of the wall. Beside this sliding shear and corner compression was also noticed as shown in Fig. 11(a). The application of ferrocement overlay prohibited these diagonal cracks in piers and a more stable crack pattern was observed as shown in Fig. 11(b). A series of small diagonal cracks were seen at the spandrel.
The final crack pattern of the Frame- 2 before and after retrofitting is shown in Fig. 12. Diagonal shear crack on the right side of the door opening was prevailing before retrofitting as shown in Fig. 12(a). After installing steel door Frame and application of ferrocement overlay no diagonal shear crack appeared; instead a diagonal shear cracks at the right corner of the door was observed and propagated towards the beam-column joint as shown in Fig. 12(b).

\subsubsection{Damage Mechanism of Frame-2}
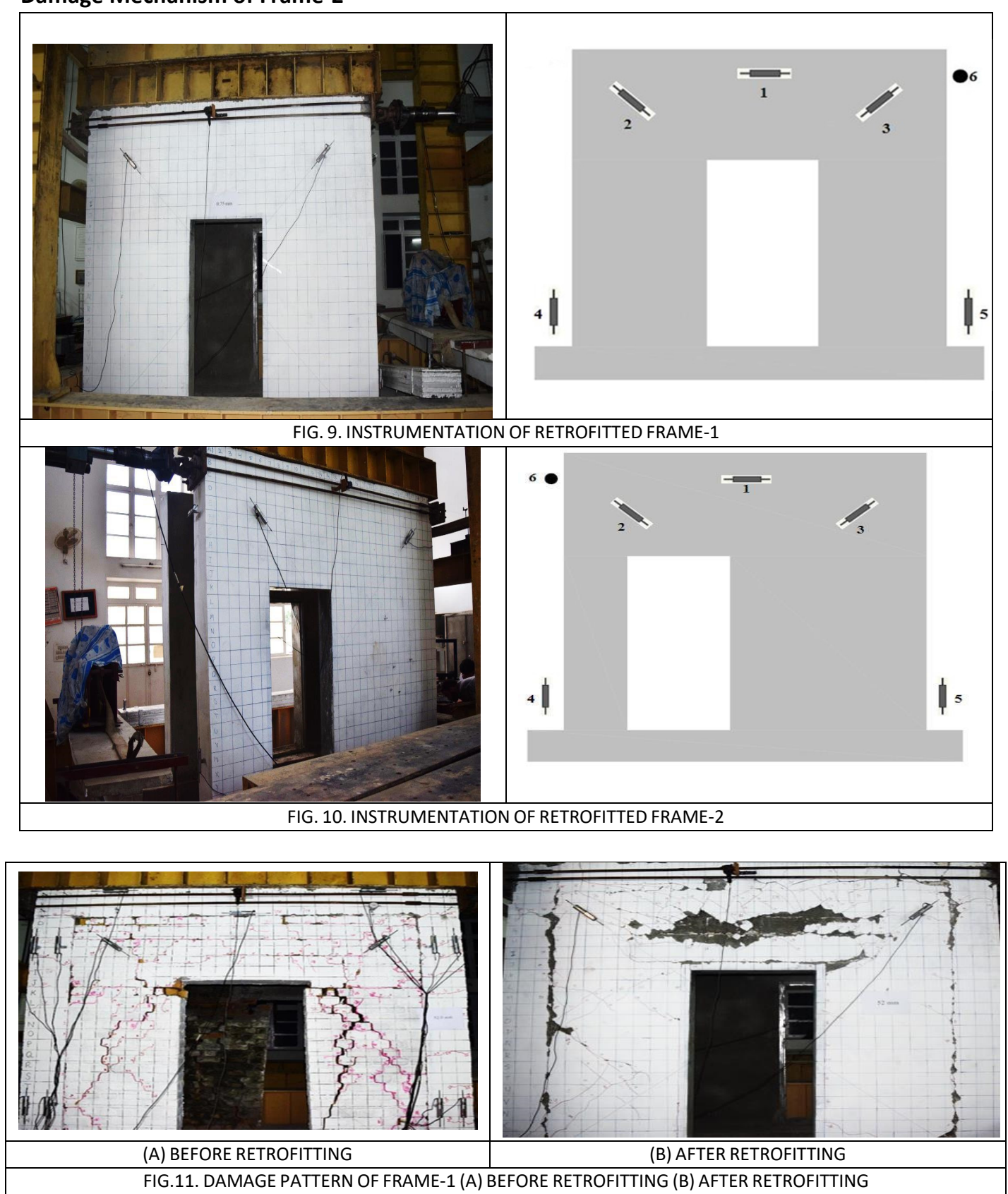


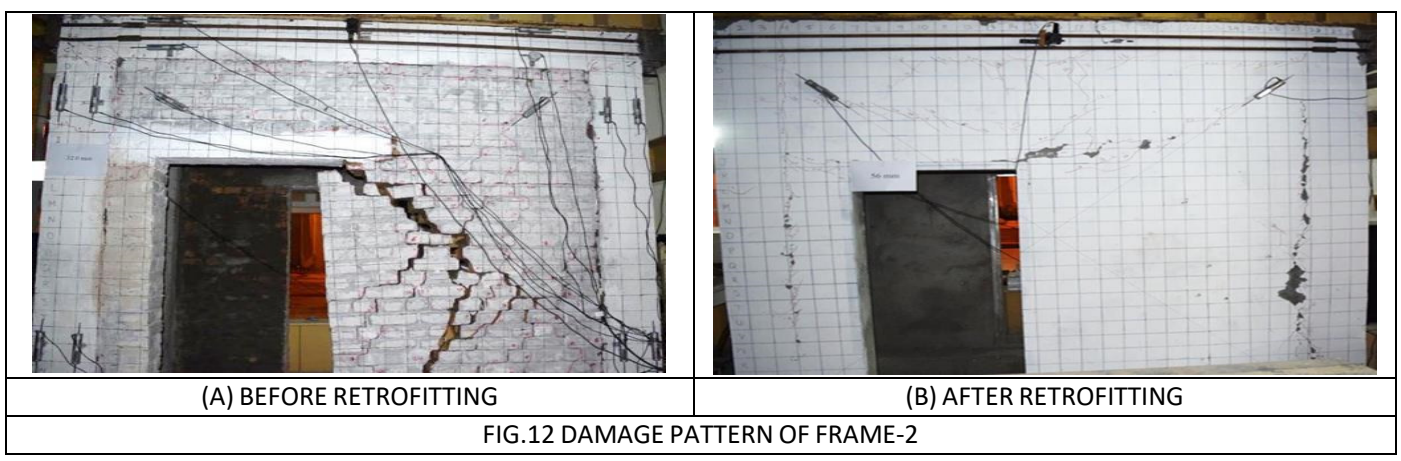

\subsection{Hysteresis Loops}

\subsubsection{Hysteresis Loops of Frame-1}

The load-deformation curves were drawn between the lateral load and percent story drift. Hysteresis loops of Frame-1 before and after retrofitting are given in Fig. 13(a-b) respectively. Before retrofitting; Frame-1 was having lower energy dissipation and slow stiffness and strength degradation. After retrofitting; the energy dissipation capacity of Frame-1 was increased, having rapid stiffness and strength degradation.

\subsubsection{Hysteresis Loops of Frame-2}

The force-deformation hysteresis loops of Frame-2 before and after retrofitting is shown in Fig. 14(a-b). From the hysteresis loops it can be understood that after retrofitting the energy dissipation was increased.
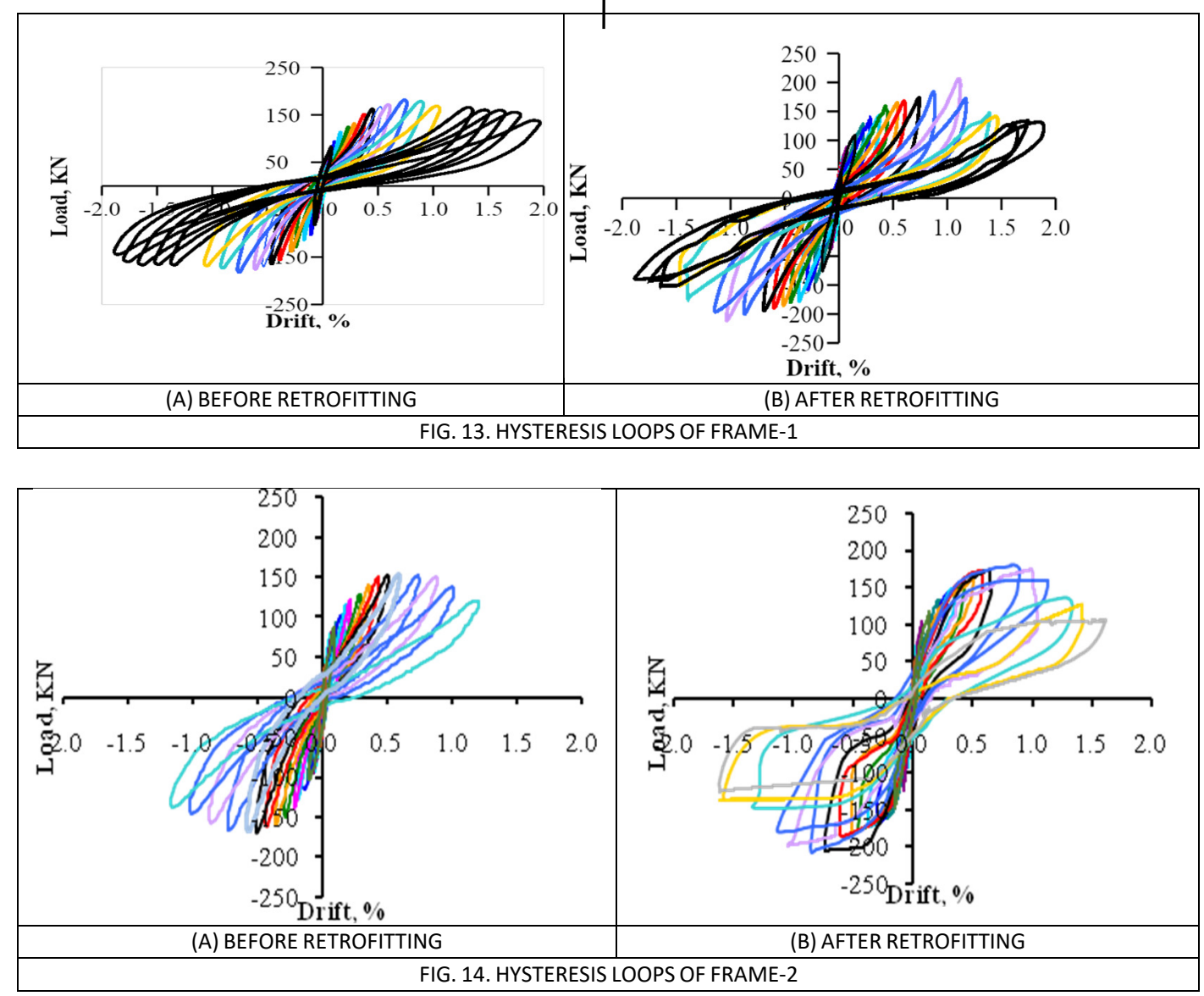

Mehran University Research Journal of Engineering and Technology, Vol. 39, No. 3, July 2020 [p-ISSN: 0254-7821, e-ISSN: 2413-7219] 


\subsection{Capacity Curve}

\subsubsection{Capacity Curve of Frame-1}

Capacity curve is also called envelope, skeleton or backbone curve and is drawn by joining the points corresponding to peak load in each displacement cycle. Before retrofitting average peak strength of $187 \mathrm{KN}$ was achieved at a story drift of $0.60 \%$ $(16.46 \mathrm{~mm})$, after which slow degradation in load started. At a drift of $1.63 \%(43 \mathrm{~mm})$, the lateral load was reduced to $19 \%$ of its maximum load. Keeping in mind that the structure has to be retrofitted the test was stopped at a story drift of i.e. 1.63\%. After retrofitting; Frame-1 reached to a maximum lateral load of $11.58 \mathrm{KN}$ at a story drift of $1.029 \%(28 \mathrm{~mm})$, after which rapid degradation in load begins. At a story drift of $1.86 \%(51 \mathrm{~mm})$, the test was stopped because the peak load of the structure reached to $36 \%$ degradation of its peak load. Capacity curves of Frame-1 before and after retrofitting are shown in Fig. 15(a-b).

\subsubsection{Capacity Curve of Frame-2}

The peak lateral load of Frame-2 before retrofitting was $160.44 \mathrm{KN}$ at $0.58 \%(16 \mathrm{~mm})$ of the story drift. At the same drift stiffness degradation starts and the test was stopped at a drift of $1.17 \%(32 \mathrm{~mm})$ as the degradation was reached to $19.84 \%$. After retrofitting Frame-2, the peak load reached to $193.46 \mathrm{KN}$ at a story drift of $0.83 \%(22.77 \mathrm{~mm})$ after which the degradation starts and continues to a drift of $1.61 \%$ (44mm) where the degradation in strength was $38 \%$ at which the test was stopped. Capacity curves of Frame-2 before and after retrofitting are shown in Fig. 16(a-b).

\subsection{Bilinear Idealization Curve}

For the idealization of backbone curve different researchers have used different curves, for this research the model adopted is shown in Fig. 17 and is utilized by Dehghani et al. [20], which is based on equal energy principle.
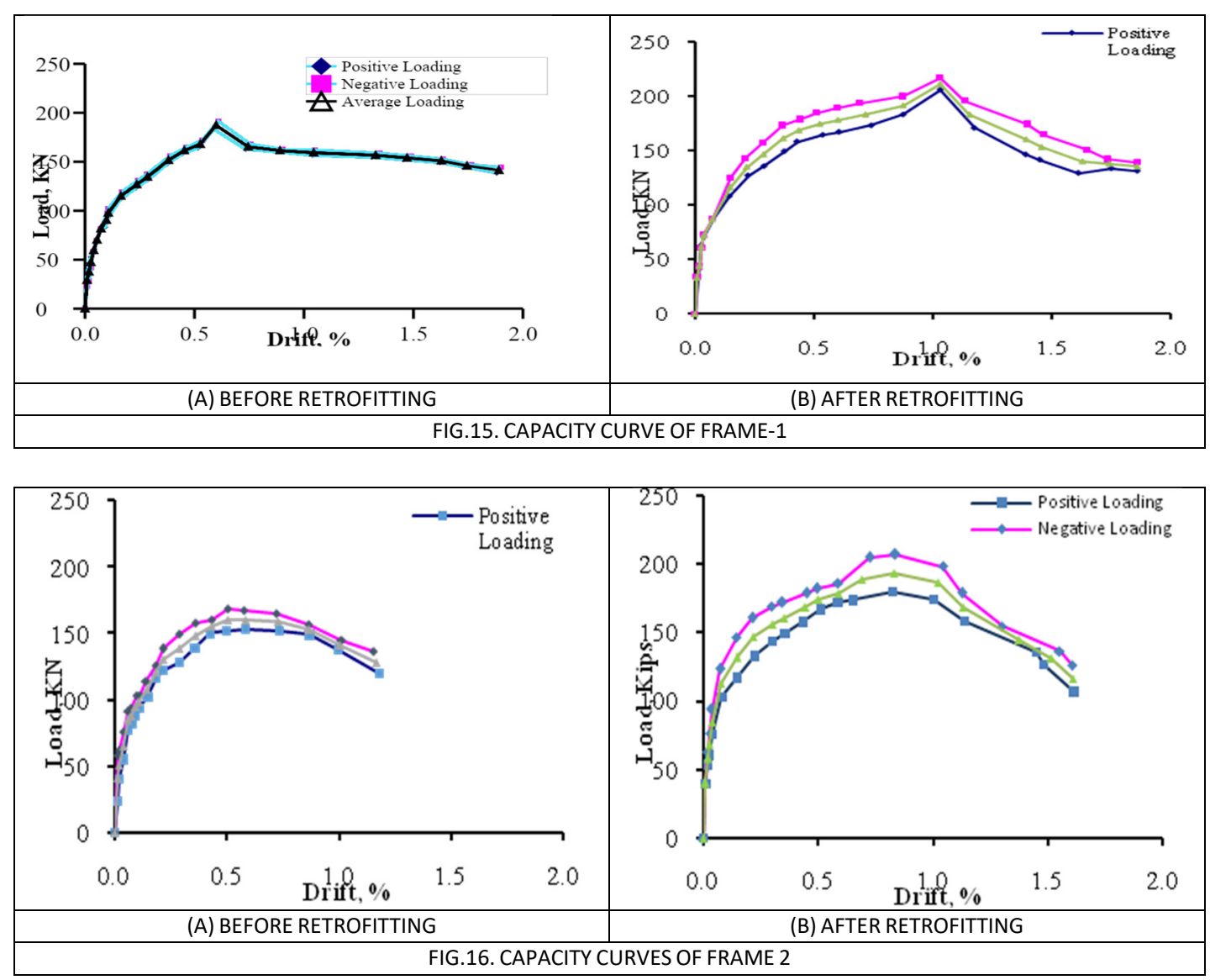

Mehran University Research Journal of Engineering and Technology, Vol. 39, No. 3, July 2020 [p-ISSN: 0254-7821, e-ISSN: 2413-7219] 


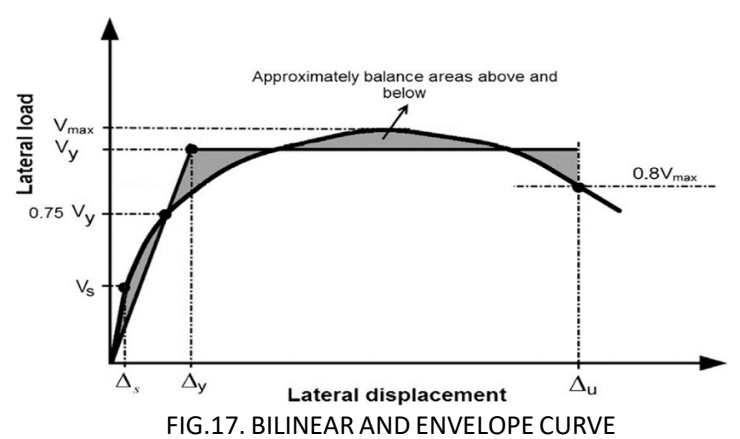

According to the said model proposed by Dehghani et al. [20] the maximum resistance taken by the structure is Vmax. The point on the actual curve where structural response deviates significantly from the elastic response and on which the first actual significant yield occurs is denoted by Vs. $\Delta \mathrm{u}$ (ultimate displacement), is the displacement point on envelope curve corresponding to $80 \%$ fall down in maximum resistance i.e. $0.8 \mathrm{Vmax}$. $\Delta \mathrm{y}$ is the yield displacement on bilinear idealization curve. Vy corresponding to the yield. To obtain equal areas under the capacity and bilinear curve, the first line of the bilinear curve should intersect with the actual curve at a lateral force of $0.75 \mathrm{Vy}$. The slope of the first line is the effective stiffness. The ratio of ultimate displacement to the yield displacement is displacement ductility $\left(\mu=\frac{\Delta_{\mathrm{u}}}{\Delta_{\mathrm{y}}}\right)$.

$\mathrm{R}_{\mathrm{s}}$ represents the Over-strength factor and was calculated by the relationship: $R_{s}=\frac{V_{y}}{V_{s}}$. The energy dissipation capacity of the structure is represented by ductility reduction $\left(R_{\mu}\right)$ and is computed as

$\mathrm{R}_{\mu}=\sqrt{2 \mu-1}$. The response modification factor $(\mathrm{R})$ was derived as $\mathrm{R}=\mathrm{Rs} \times \mathrm{R} \mu$ (product of over-strength factor and ductility).

Displacement ductility $\left(\mu_{\mathrm{D}}\right)$, Effective stiffness ( $\left.\mathrm{K}_{\mathrm{eff}}\right)$ and Force Reduction factor ( $\mathrm{R}$ ) for Frame-1 before and after retrofitting was calculated from the Fig. 18(a-b) and the obtained values of Frame- 1 are tabulated in Table 2 .

\subsubsection{Bilinear Idealization of Frame-1 before and after Retrofitting}

Bays of frames and infills deform in flexural and shear modes as lateral deformations increase under the application of horizontal loads. Alternate tension and compression diagonals generates in the wall panels due to lateral displacement cycles. Infilled frames behave like unidirectional braced systems in which the separation between frame and infills is caused along the tension diagonal by the relative displacements while struts are formed on the compression diagonal.

\begin{tabular}{|c|c|c|c|}
\hline \multicolumn{4}{|c|}{$\begin{array}{l}\text { TABLE 2. FRAME-1 SEISMIC PARAMETERS BEFORE AND AFTER } \\
\text { RETROFITTING }\end{array}$} \\
\hline Description & $\begin{array}{c}\text { Before } \\
\text { Retrofitting }\end{array}$ & $\begin{array}{l}\text { After } \\
\text { Retro- } \\
\text { fitting }\end{array}$ & $\begin{array}{l}\text { Ratio } \\
\text { (After/ } \\
\text { Before) }\end{array}$ \\
\hline $\begin{array}{c}\text { Lateral Load, } \\
\text { KN }\end{array}$ & 187 & 211.58 & 1.13 \\
\hline $\mathrm{K}_{\mathrm{eff}}(\mathrm{KN} / \mathrm{mm})$ & 21.95 & 25.78 & 1.17 \\
\hline $\begin{array}{l}\text { Ductility } \\
\text { Factor }(\mu)\end{array}$ & 6.17 & 5.42 & 0.88 \\
\hline $\begin{array}{c}\text { Ductility } \\
\text { Reduction } \\
\text { Factor, } \\
\mathrm{R}_{\mu}=\sqrt{2 \mu-1}\end{array}$ & 3.37 & 3.14 & 0.93 \\
\hline $\begin{array}{l}\text { Overstrength } \\
\text { Factor }(\Omega)\end{array}$ & 1.97 & 2.36 & 1.20 \\
\hline $\begin{array}{c}\text { Force } \\
\text { Reduction } \\
\text { Factor, } \mathrm{R}=\mathrm{R} \mu \\
\mathrm{x} \Omega\end{array}$ & 6.65 & 7.42 & 1.16 \\
\hline
\end{tabular}

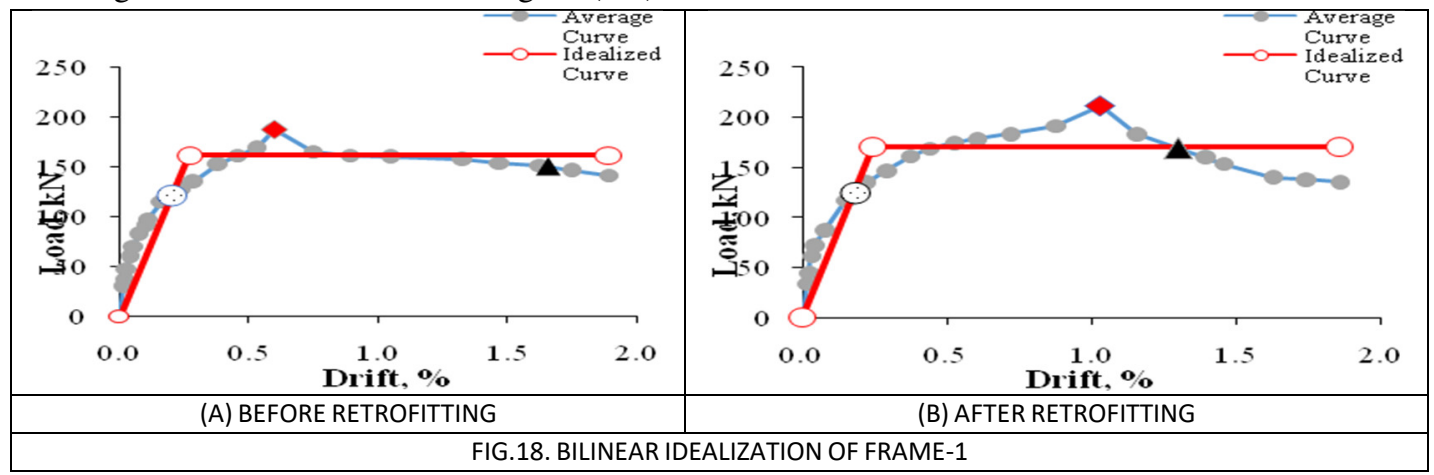

Mehran University Research Journal of Engineering and Technology, Vol. 39, No. 3, July 2020 [p-ISSN: 0254-7821, e-ISSN: 2413-7219] 


\subsubsection{Bilinear Idealization of Frame-2 before and after Retrofitting}

Important Parameters for Frame-2 before and after retrofitting were calculated from Fig.19(a-b). The numerical values obtained are given in Table 3 .

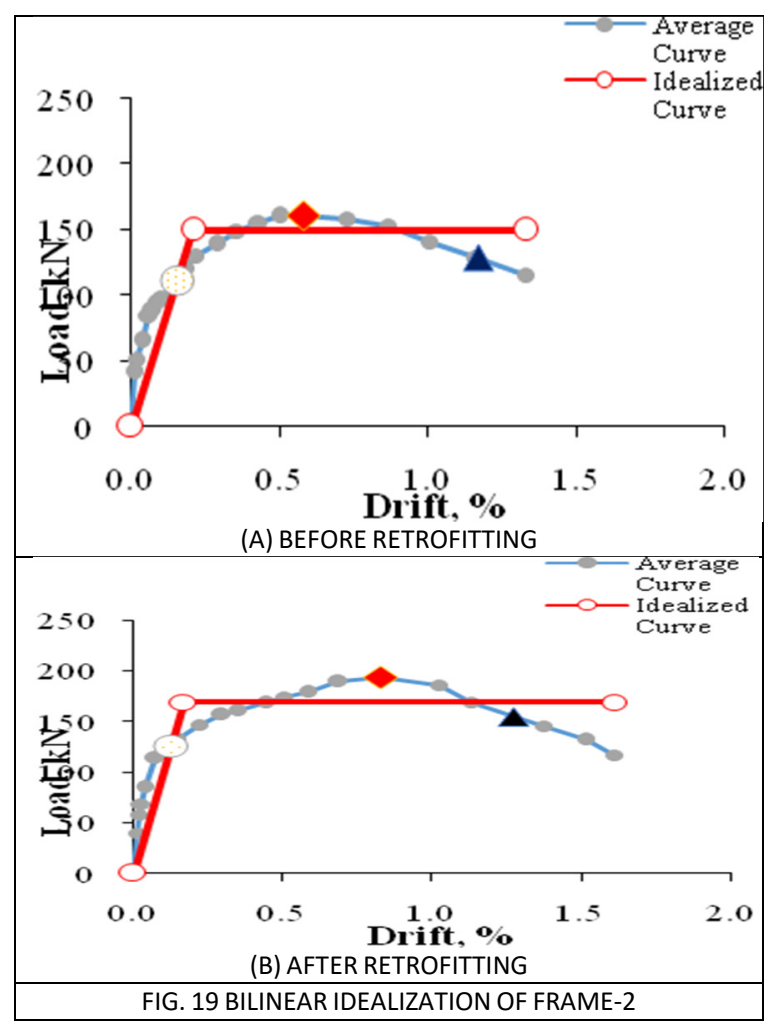

\begin{tabular}{|c|c|c|c|}
\hline \multicolumn{4}{|c|}{ TABLE3: FRAME-2 SEISMIC PARAMETERS BEFORE AND AFTER } \\
\hline Description & $\begin{array}{c}\text { Before } \\
\text { Retro- } \\
\text { fitting }\end{array}$ & $\begin{array}{c}\text { After } \\
\text { Retro- } \\
\text { fitting }\end{array}$ & $\begin{array}{c}\text { Ratio } \\
\text { (After/ } \\
\text { Before) }\end{array}$ \\
\hline $\begin{array}{c}\text { Lateral Load, } \\
\text { KN }\end{array}$ & 160.44 & 193.46 & 1.21 \\
\hline $\mathrm{K}_{\text {eff }}(\mathrm{KN} / \mathrm{mm})$ & 26.07 & 36.45 & 1.40 \\
\hline $\begin{array}{c}\text { Ductility Factor } \\
(\mu)\end{array}$ & 7.46 & 7.59 & 1.02 \\
\hline $\begin{array}{c}\text { Ductility } \\
\text { Reduction } \\
\text { Factor, } \\
\mathrm{R}_{\mu}=\sqrt{2 \mu-1}\end{array}$ & 3.73 & 3.77 & 1.01 \\
\hline $\begin{array}{c}\text { Overstrength } \\
\text { Factor }(\Omega)\end{array}$ & 1.77 & 1.20 & 0.68 \\
\hline $\begin{array}{c}\text { Force Reduction } \\
\text { Factor, R= R } \mu \mathrm{x} \\
\Omega\end{array}$ & 6.60 & 7.52 & 1.14 \\
\hline
\end{tabular}

\subsection{ASCE PERFORMANCE LEVELS}

There are three ASCE performance levels as shown in Fig. 20.

(i) Immediate Occupancy (IO) Performance Level

(ii) Life Safety (LS) Performance Level

(iii) Collapse Prevention (CP) Performance Level

Immediate Occupancy: A point corresponding to yield drift or $0.1 \%$ of the ultimate drifts on capacity curve.

Life Safety (LS): Point (0.75 times the ultimate drift) on capacity curve corresponds to life safety.

Collapse Prevention (CP): Point on capacity curve having $20 \%$ decrease in the lateral strength.

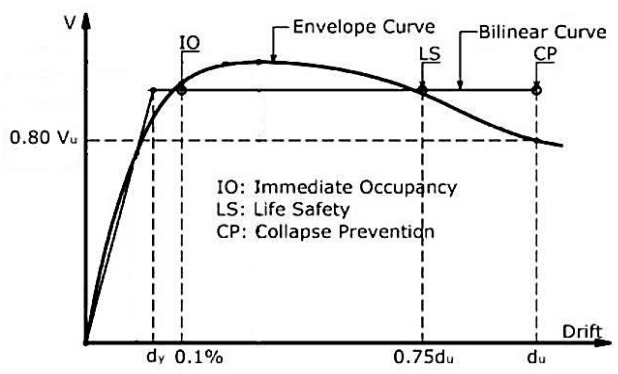

FIG. 20: PERFORMANCE LEVELS (ASCE/SEI 41-06)

\subsubsection{Frame-1 ASCE Performance Levels Before and After Retrofitting}

Before retrofitting the immediate occupancy, life safety and collapse prevention was at a story drift of $0.27,1.24$ and $1.65 \%$ respectively as shown in Fig. 21(a). After strengthening Frame-1, the immediate occupancy reached to a story drift of $0.26 \%$, life safety to $0.975 \%$ and collapse prevention was obtained at $1.30 \%$ as shown in Fig. 21(b). Comparison of performance levels is shown in Fig. 22.

\subsubsection{Frame-2 ASCE Performance Levels Before and After Retrofitting}

Before retrofitting the immediate occupancy, life safety and collapse prevention was at a story drift of $0.21,0.88$ and $1.17 \%$ respectively as shown in Fig. 
23(a). After strengthening Frame-2, the immediate occupancy reached to a story drift of $0.17 \%$, life safety to $0.96 \%$ and collapse prevention was obtained at $1.28 \%$ as shown in Fig. 23(b). Comparison of performance levels is shown in Fig. 24.

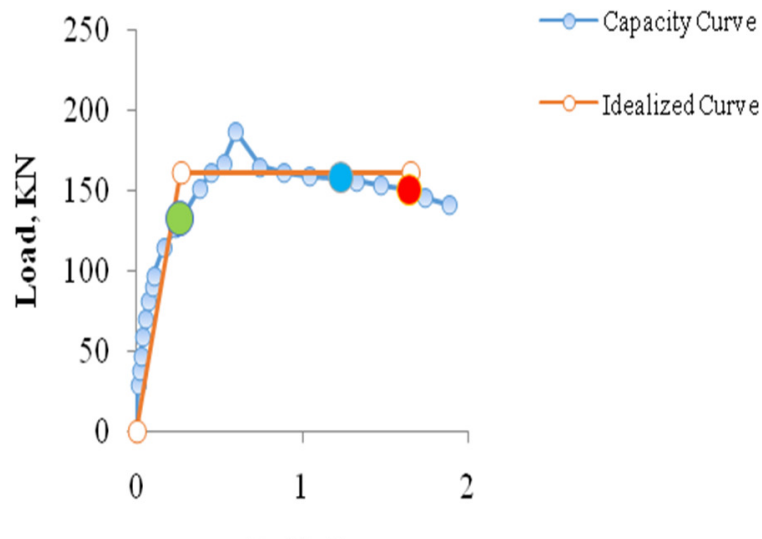

Drift, $\%$

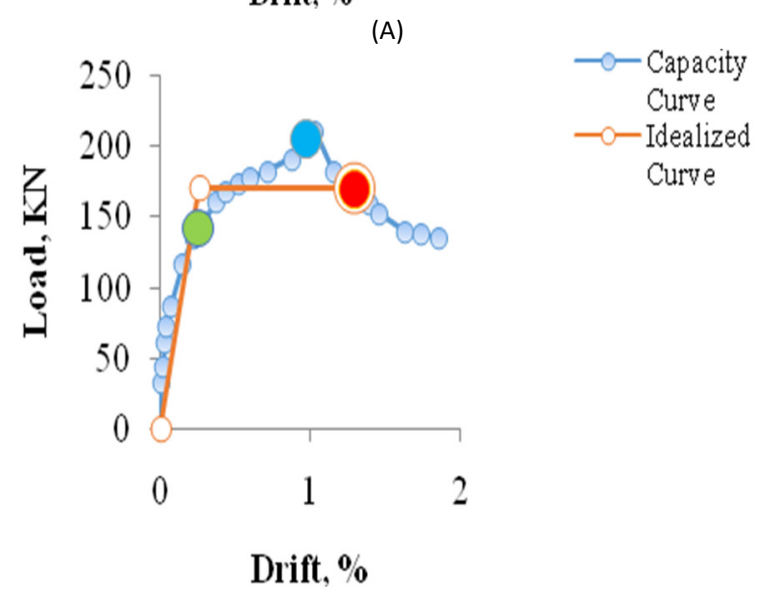

(B)

FIG. 21. PERFORMANCE LeVELS Of FRAME-1 (A) BEFORE RETROFITTING (B) AFTER RETROFITTING

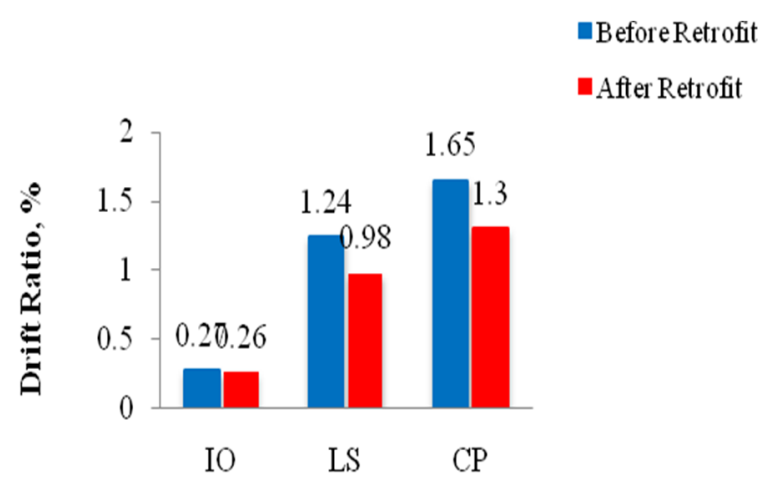

Performance I evels

FIG. 22. COMPARISON OF PERFORMANCE LEVELS OF FRAME-1 BEFORE AND AFTER RETROFITTING
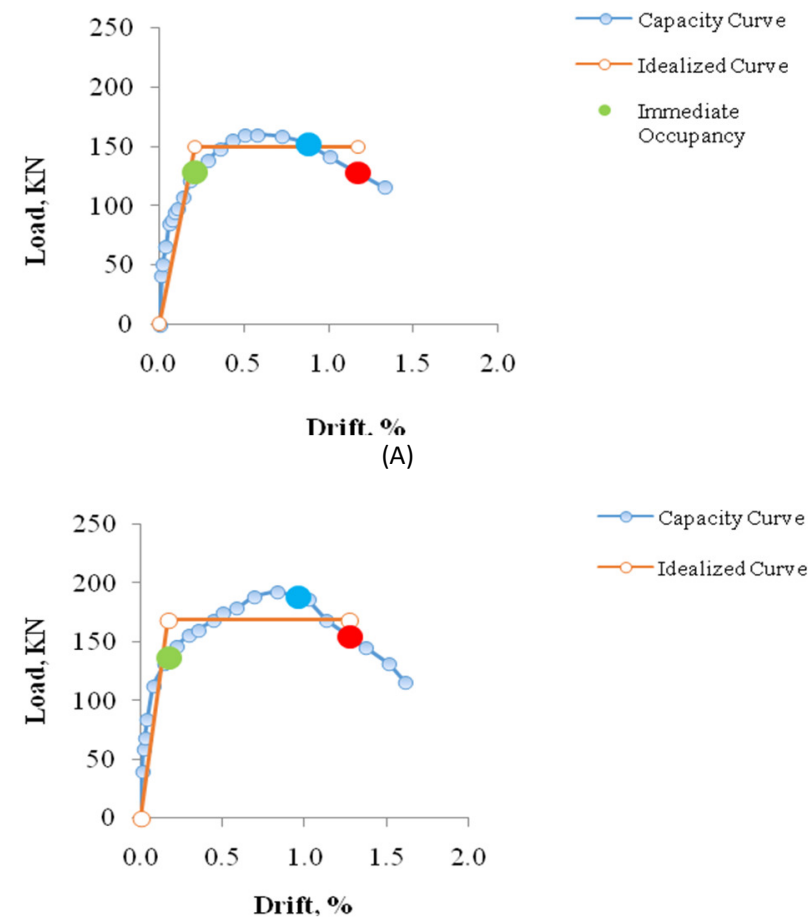

(B)

FIG. 23. PERFORMANCE LEVELS OF FRAME-2 (A) BEFORE RETROFITTING (B) AFTER RETROFITTING

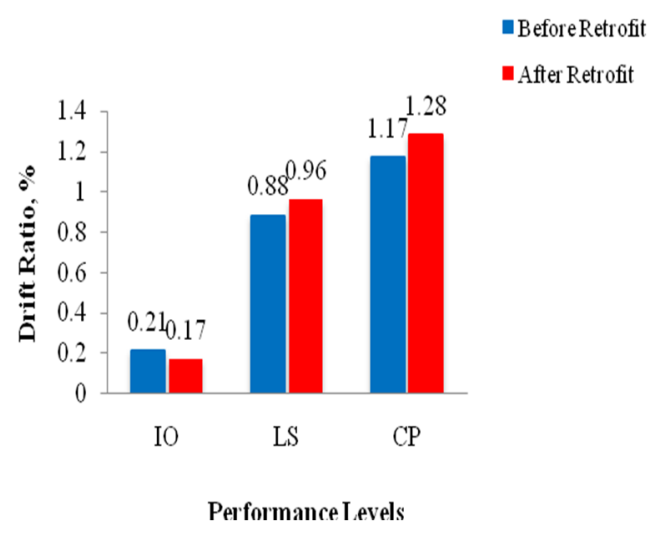

\section{CONCLUSIONS}

The experimental study discussed in this research paper focused on the seismic performance of full scaled infilled frames having doors at different locations with reinforced plaster, grout injection and installation of steel door frames. The RC frames were detailed and constructed in the laboratory based on the current construction practices in Pakistan and tested under quasi-static lateral loading before and after retrofitting. The following conclusions were drawn from the experimental study. 
(i) Frame-1 and Frame-2 showed $13 \%$ and $21 \%$ increase in the lateral load carrying capacity.

(ii) The effective stiffness of retrofitted Frame-1 and Frame-2 was found to be much higher than that of original frames due to the reinforced plaster and steel door frames. There was an increase of 17 and 40 percent in the effective stiffness of retrofitted Frame-1 and Frame-2 respectively.

(iii) The idealized curves developed from the capacity curve before and after retrofitting revealed that applying ferrocement overlay on Frame-1 decreased the ductility factor $(\mu)$ by $12 \%$ while in case of Frame-2, ductility factor increased by $2 \%$.

(iv) From the bilinear idealized curve it was concluded that $8 \%$ decrease in yield displacement occurred in case of Frame-1 while in case of Frame- 2 a decrease of $23.5 \%$ was obtained due to the significant increase in stiffness.

(v) Hysteresis loops obtained for retrofitted Frame-1 and Frame-2 showed an increase in the cumulative dissipated energy with respect to the parent specimens. It means that more energy was dissipated by the retrofitted specimens.

(vi) ASCE performance levels or drift levels achieved from the capacity curve after performing the test on retrofitted specimen exhibited that applying Ferrocement overlay and installation of steel door frames masonry infill postponed damages to a higher drift levels.

(vii) For Frame-1 before retrofitting immediate occupancy, life safety and collapse prevention was at a story drift of $0.27 \%$, $1.24 \%$ and $1.65 \%$ respectively. After strengthening Frame-1, the immediate occupancy reached to a story drift of $0.26 \%$, life safety to $0.98 \%$ and collapse prevention was obtained at $1.30 \%$.

(viii) The immediate occupancy, life safety and collapse prevention for Frame-2 before retrofitting were obtained at a story drift of $0.21 \%, 0.88 \%$ and $1.17 \%$ respectively. After retrofitting Frame-2, the immediate occupancy reached to a story drift of $0.17 \%$, life safety to $0.96 \%$ and collapse prevention was obtained at $1.28 \%$.

(ix) Crack pattern developed within the retrofitted Frame-1 and Frame-2 showed that ferrocement overlay and installation of steel door frames prohibit the origination of diagonal cracks from the door corners, also no shear cracks and corner compression was observed.

(x) There is an increase of $16 \%$ and $14 \%$ in the force reduction factor of Frame-1 and Frame2 after retrofitting respectively.

\section{ACKNOWLEDGMENT}

The authors are very thankful and gratefully acknowledge the financial support of Higher Education Commission, Government of Pakistan.

\section{REFERENCES}

[1] Shah, A., Qureshi, M., Abbas, S.W., and Naseer, S., "An Analysis of Seismic Provisions of Building Code of Pakistan", 5th World Engineering Congress (WEC 2013), pp. 23-25, NUST, Islamabad, 2013.

[2] Munir, A., Naseer, A., Badshah, E., "RC Buildings Construction Practices (After 2005 Kashmir Earthquake) in Urban Areas of High Seismic Zone of Northern Pakistan", Environmentally Sustainable Development Proceedings (ESDev VII $\quad-2017$ Conference), pp. 93-101, CIIT Abbottabad, 2017.

[3] Abdel-Hafez, LM., Abouelezz, AE., Elzefeary, FF., "Behavior of masonry strengthened infilled reinforced concrete frames under in-plane load", HBRC Journal. Vol.11, No.2, pp.213-223, 2015.

[4] Tsionis, G., Apostolska, R., Taucer, F., "Seismic strengthening of RC buildings", JRC Science and Policy Reports. pp.138-156, 2014.

[5] Chen, YF., Liu, J., Shi, Y., "Retrofitting of a seismically deficient building", Journal of Structural Integrity and Maintenance, Vol. 1, No. 3, pp.107-113, 2016. 
[6] Khan, AH., Imran, A., Hussain, M., "Evaluation of Quality during Construction Projects: A Case Study of Pakistan”, Mehran University Research Journal of Engineering and Technology. Vol. 38, No. 1, pp. 69-82, 2019.

[7] Ashraf, M., "Development of cost-effective and efficient retrofitting technique for masonry buildings in Pakistan", Ph.D Research, Department of Civil Engineering, University of Engineering and Technology Peshawar, Pakistan. 2010.

[8] Ashraf, M., Naeem Khan, A., Ali, Q., Shahzada, K., Naseer, A., "Experimental behavior of full scale URM building retrofitted with ferrocement overlay", In Advanced Materials Research, Vol. 255, pp. 319-323, 2011

[9] Reinhorn, AM., Prawel, SP., Jia, ZH., "Experimental study of ferrocement as a seismic retrofit material for masonry walls", Journal of ferrocement, Vol. 15, No. 3, pp. 247-260, 1985.

[10] Acun, B., Sucuoglu, H., "Strengthening of masonry infill walls in reinforced concrete frames with wire mesh reinforcement", In Proceedings of the 8th US National Conference on Earthquake Engineering, 2006.

[11] Ahmad, Z., Shahzada, K., Gencturk, B., Naeem Khan, A., Rehan, R., Fahad, M., Ashraf, M., Ali, Z., "Seismic capacity assessment of unreinforced concrete block masonry buildings in Pakistan before and after retrofitting", Journal of Earthquake Engineering. Vol. 19, No. 3, pp. 357-382, 2015.

[12] Ali Shah, SM., Shahzada, K., Gencturk, B., Memon, SA., "Retrofitting of full-scale confined masonry building using ferrocement overlay" Journal of Performance of Constructed Facilities. Vol. 31, No. 5, pp04017079, 2017.

[13] Amanat, KM., Alam, MM., Alam, MS., "Experimental investigation of the use of ferrocement laminates for repairing masonry in filled RC frames", Journal of Civil Engineering (IEB), Vol.35, No. 2, pp.71-80, 2007.

[14] Kim, SH., Kim, DK., "Seismic retrofit of rectangular RC bridge columns using wire mesh wrap casing", KSCE Journal of Civil Engineering. Vol. 15, No. 7, pp, 1227-1236, 2011,

[15] Abd-ELhamed, MK., Ezz-Eldeen, HA., "Retrofitting and Strengthening of Damaged Reinforced Concrete Columns Using Steel Angels Wrapped with Steel Wire Mesh", International Journal of Modern Engineering Research (IJMER). Vol. 4, No. 12, pp, 16-24, 2014.

[16] Miha, T., "Earthquake-resistant Design of Masonry Buildings", World Scientific, Vol. $1,1999$.

[17] Schuller, M., Atkinson, R., Borgsmiller, J., "Injection grouting for repair and retrofit of unreinforced masonry" In Proceedings of the 10th International Brick and Block Masonry Conference, Calgary, Canada, 1994.

[18] Manzouri, T., Schuller, MP., Shing, PB., Amadei, B., "Repair and retrofit of unreinforced masonry structures" Earthquake Spectra. Vol.12, No. 4, pp.903-922, 1996.

[19] Ali Shah, SA., "Seismic Performance Evaluation of Indigenous Brick Masonry Infill Panel Walls in Reinforced Concrete Structures", Ph.D Research, Department of Civil Engineering, University of Engineering and Technology Peshawar, Pakistan, 2018.

[20] Dehghani, A., Nateghi-Alahi, F., Fischer, G., "Engineered cementitious composites for strengthening masonry infilled reinforced concrete frames", Engineering Structures. Vol.105, pp.197-208, 2015. 